\title{
ANALISIS YURIDIS TERHADAP PENYALAHGUNAAN NARKOTIKA JENIS SABU-SABU DAN PIL EKSTASI DITINJAU DARI SEGI HUKUM PIDANA DALAM PUTUSAN NOMOR : 473/PID.SUS/2015/PT.MDN
}

Oleh:

\author{
Sanna Friani Manalu ${ }^{1)}$, Arta Rumiris Sipahutar ${ }^{2)}$, Sampe Raja Sinaga ${ }^{3)}$ dan \\ Mesias J.P Sagala ${ }^{4)}$
}

\author{
Universitas Prima Indonesia ${ }^{1,2,3,4)}$
}

E-Mail :

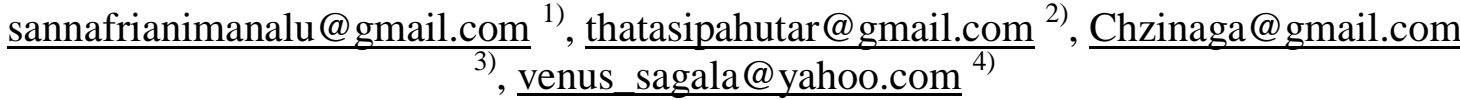

\begin{abstract}
The study was intended to explore the application of law for drug abusers of the type of methamphetamine based on court decision No. 473 / PID.SUS / 2015 / PT.MDN. Narcotics is an interesting issue to discuss because it is always followed by opinions that are pro and contra. The provision of criminal law can be interpreted as one of the penalties given to someone who violates the applicable law. In this case, a narcotics addict can be considered a violator of the law, because he has been abusing drugs. In accordance with the times, which are marked by technological advances, information and communication can multiply people to engage in criminal acts. The results of this study indicated that the application of material criminal law to decision No. 473 / PID.SUS / 2015 / PT.MDN had to be in accordance with the demands of the public prosecutor. Because in the statement of the defendant disclosed in court, (1) it was mentioned that there was a sale and purchase transaction carried out by the defendant with someone he did not know. (2) Legal considerations against judges who imposed criminal sanctions on the verdict No. 473 / PID.SUS / 2015 / PT.MDN had to be based on the consideration of the public prosecutor and judge, the offender could be sentenced to life imprisonment or at least imprisonment for 5 years or a maximum of 20 years and a fine of at least 1 billion rupiahs or at most 10 billion rupiahs by applying article 114 paragraph (1) of Law No. 352009 on narcotics.
\end{abstract}

Keywords: Narcotics, Sabu-Sabu, Abuse

\section{PENDAHULUAN}

Pada era globalisasi seperti sekarang ini, masyarakat semakin cepat berkembang. Hal ini disebabkan oleh kemajuan ilmu pengetahuan dan pola pikir masyarakat yang setiap harinya semakin berfikir luas dalam mengespresikan diri sendiri. Perkembangan tersebut seharusnya diikuti dengan proses penyesuaian diri yang kadang-kadang proses tersebut terjadi secara tidak seimbang. Hal ini jugalah yang dapat menyebabkan seseorang melakukan pelanggaran terhadap norma-norma atau melakukan tindak kejahatan.

Secara yuridis formal, kejahatan adalah bentuk tingkah laku yang bertentangan dengan moral kemanusiaan (immoril), merupakan masyarakat, asosial sifatnya dan melanggar hukum sertaundang-undang pidana. Secara sosiologis, kejahatan adalah semua ucapan, perbuatan dan tingkah lakuyang 
secara ekonomis, politis dan osial psikologis sangat merugikan masyarakat, melanggar norma-norma susila dan menyerang keselamatan warga masyarakat (baik yang telah tercantum dalam undang-undang pidana). Kejahatan merupakan salah satu bentuk perilaku manusia kepada manusia lainnya yang dapat dikatakan perilaku menyimpang atau setiap tingkah laku manusia yang melanggar aturan hukum pidana.Suatu perbuatan tersebut dianggap bukan kejahatan apabila perbuatan tersebut tidak dilarang di dalam aturan hukum pidana.Kejahatan juga merupakan bagian dari kehidupan masyarakat dan merupakan peristiwa yang dialami manusia sehari-hari. Oleh karena itu kejahatan merupakan fenomena sosial yang bersifat universal dalam kehidupan manusia. Pada kejahatan terdapat pula unsur-unsur kejahatan yaitu :

1. Kejahatan pertama adalah perbuatanyang dapat membuat kerugian bagi orang lain.

2. Kejahatan kedua adalah harus tercantum dalam kitab UndangUndang Hukum Pidana.

3. Kejahatan ketiga adalah terdapat makna jahat atau niat jahat didalamnya

4. Kejahatan keempat adalah terdapat penggabungan antara makna jahat atau niat jahat dan perbuatan jahat.

5. Kejahatan kelima adalah terdapat penggabungan antara perbuatan dengan kerugian yang tercantum dalam kitab Undang-Undang Hukum Pidana.

6. Kejahatan keenam adalah harus terdapat sanksi pidana yang mengancam perbuatan tersebut.

Menurut Light, Keller dan Calhoun, bentuk kejahatan ada empat, yaitu:

1. White Collar Crime (Kejahatan Kerah Putih)

2. Crime Without Victim (Kejahatan Tanpa Korban)

3. Organized Crime (Kejahatan Terorganisir)

4. Corporate Crime (Kejahatan Korporasi)
Narkotika sebagai bahan-bahan yang terutama mempunyai efek kerja pembiusan atau dapat menurunkan kesadaran. Narkoba mengatakanbahwa narkotika adalah zat yang dapat menimbulkan perubahan perasaan, susunan pengamatan atau penglihatan karena zat tersebut mempengaruhi susunansaraf. Semula obat ini ditujukan untuk kepentingan pengobatan contohnya sebagai bius dalam kegiatan operasi kedokteran, dan sangat berbahaya jika disalahgunakan karena apabila disalahgunakan akan membahayakan si pemakai dan dapat menjadi pecandu narkotika atau sering juga disebut ketergantungan pada narkotika.

Setiap orang yang menyalahgunakan zat-zat terlarang pasti memiliki alasan mereka masing-masing sehingga mereka dapat terjebak masuk ke dalam perangkap narkotika, narkoba atau zat adiktif. Beberapa faktor penyebab seseorang menjadi pecandu atau pengguna zat terlarang adalah:

1. Ingin Terlihat Gaya

2. Solidaritas Kelompok/Komunitas/Geng

3. Menghilangkan Rasa Sakit

4. Coba-Coba atau Ingin Tahu

5. Ikut-ikutan

6. Menyelesaikan dan Melupakan Masalah/Beban Stres

7. Menonjolkan Sisi Pemberontakan atau Merasa Hebat

8. Menghilangkan Rasa Penat dan Bosan

9. Mencari Tantangan atau Kegiatan Beresiko

10. Merasa Dewasa

Berdasarkan akibat yang ditimbulkan, penyalahgunaan narkoba dibedakan menjadi 3 yaitu:

1. Depresan, yaitu menekan sistem sistem syaraf pusat dan mengurangi aktifitas fungsional tubuh sehingga pemakai merasa tenang, bahkan bisa membuat pemakai tidur dan tak sadarkan diri. Bila kelebihan dosis bisa mengakibatkan kematian.

2. Stimulan, merangsang fungsi tubuh dan meningkatkan kegairahan serta kesadaran. 
3. Halusinasi, akibat yang ditimbulkan dapat berhalusinasi dan merubah persepsi seseorang terhadap sesuatu. Akibat Penyalahgunaan Narkoba Bagi Diri Sendiri Secara Fisik terdiri dari:

1. Wajah menjadi pucat

2. Buang air besar tidak lancar

3. Berat badan semakin turun drastic

4. Bibir berubah warna menjadi hitam

5. Mata menjadi merah dan cekung

6. Mengalami Gangguan pada system saraf

7. Paru-paru (pulmoner) akan terganggu

8. Mengalami sering sakit kepala, suhu tubuh menjadi meningkat, mual-mual dan muntah.

9. Akan merdampak pada kesehatan reproduksi

10. Berdampak pada kesehatan reproduksi pada remaja perempuan.

Dampak Penyalahgunaan Narkoba

Terhadap Psikis terdiri dari:

1. Sangat sensitif dan cepat bosan.

2. Nafsu makan hilang.

3. Tegang dan gelisah menjadi sangat sering

4. Kepercayaan diri menjadi hilang, sering berkhayal, apatis, dan penuh curiga.

5. Susah konsentrasi, tertekan dan perasaan kesal.

6. Sering menyakiti diri dan perasaan menjadi tidak nyaman.

Dampak Penyalahgunaan Narkoba

Terhadap Lingkungan Sosial terdiri dari:

1. Mengganggu proses pendidikan serta akan membuat masa depan menjadi suram.

2. Keluarga merasa direpotkan dan menjadi terbebani karena mengalami gangguan mental, dikucilkan oleh lingkungan sekitar, asusila dan antisosial.

Penyalahgunaan narkotika tampaknya tampaknya semakin merajalela, terutama di kota-kota besar yang merupakan tempat terjangkitnya wabah narkotika yang seolah-olah tidak dapat di bendung lagi.Akhir-akhir ini penyalahgunaan narkotika tidak saja menjadi kendala di kota-kota besar tetapi mulai merembes ke desa.
Masalah penyalahgunaan narkotika di Indonesia sekarang ini dirasakan gawat dan bersifat internasional yang dilakukan dengan modus operandi dan teknologi yang canggih. Sebagai negara kepulauan yang mempunyai letak strategis, Indonesia telah ikut berpatisipasi menanggulangi kejahatan penyalahgunaan narkotika, yaitu dengan diundang-undangkannya Undang-Undang Nomor 35 Tahun 2009 tentang Narkotika. Undang-undang ini merupakan undangundang yang baru menggantikan undangundang yang lama yaitu Undang-Undang Nomor 22 Tahun 1997 dan Undangundang Nomor 35 Tahun 2009 tentang Narkotika.

Berdasarkan Undang-Undang Nomor 35 Tahun 2009, setiap pelaku penyalahgunaan narkotika dapat dikenakan sanksi pidana, yang berarti penyalahguna narkotika dapat disebut sebagai pelaku perbuatan pidana narkotika. Harus disadari bahwa masalah penyalahgunaan narkotika adalah suatu problema yang sangat kompleks, oleh karena itu diperlukan upaya dan dukungan dari semua pihak agar dapat mencapai tujuan yang diharapkan, karena pelaksanaan undang-undang, sangat tergantung pada partisipasi semua pihak baik pemerintah, aparat keamanan, keluarga, lingkungan, sebab hal tersebut tidak dapat hilang dengan sendirinya. Perkembangan penyalahgunaan narkotika yang semakin meningkat dan bervariasi motif penyalahgunaan dan pelakunya, karena tidak sedikit yang melakukannya adalah dari kalangan anak-anak dan remaja yang merupakan generasi penerus bangsa.

Upaya memberantas kejahatan narkotika yang bersifat internasional tersebut dengan cara merutinkan adanya razia atau operasi barang-barang zat yang berbahaya seperti miras, obat-obatan. Pidana seharusnya lebih dititik-beratkan kepada pengedar narkotika karena dengan adanya pengedar yang menyebabkan munculnya penyalahgunaan Narkotika yang kemudian melahirkan seorang pecandu 
narkotika, karena biar bagaimanapun pemberantasan Narkotika harus dilihat titik sentralnya, sulitnya aparat penegak hukum melakukan pelacakan terhadap pengedaran Narkotika dikarenakan kejahatan tersebut dilakukan tidak secara perseorangan melaikan melibatkan banyak orang yang secara bersama-sama bahkan merupakan satu sindikat yang terorganisasi dengan jaringan luas yang bekerja secara rapi dan sangat rahasia baik di tingkat nasional maupun Internasional.

Hal yang menarik dalam undangundang tentang narkotika adalah kewenangan hakim untuk menjatuhkan vonis bagi seseorang yang terbukti sebagai pecandu narkotika untuk dilakukannya Rehabilitasi, secara tersirat kewenangan ini, mengakui bahwa pecandu narkotika, selain sebagai pelaku tindak pidana juga sekaligus korban dari kejahatan itu sendiri. Uraian dalam pasalnya menitikberatkan pada kekuasaan hakim dalam memutus perkara narkotika, sayangnya rumusan tersebut tidak efektif dalam kenyataannya Peradilan terhadap pecandu narkotika sebagian besar berakhir dengan vonis pemenjaraan dan bukan vonis rehabilitasi sebagaimana yang tercantum dalam undang-undang tersebut.

Pidana penjara bagi pengedar narkotika terbukti tidak dapat menurunkan jumlah penyalahguna narkotika, begitupun sebaliknya, penegak hukum dan pembentuk Undang-Undang seharusnya membedakan antara pengedar dan pengguna serta harus ada perubahan paradigma di dalam masyarakat terhadap seorang pengguna Narkotika.

\section{a. Rumusan Masalah}

Berdasarkan latar belakang di atas maka yang menjadi permasalahan dalam skripsi ini adalah sebagai berikut :

1. Bagaimana Penerapan Undang-Undang No. 35 Tahun 2009 Dalam Penegakan Hukum Bagi Pengedar Narkoba?

2. Sejauh manakah hukuman yang dapat dijatuhkan kepada pengedar narkotika jenis sabu-sabu?
3. Bagaimana Kebijakan Hakim Terhadap Tindak Pidana Sebagai Pengedar Narkotika Jenis Sabu-Sabu (Putusan Nomor 473/PID.SUS/2015/PT.MDN.)?

\section{METODE PELAKSANAAN}

Jenis penelitian ini lebih menitikberatkan pada penelitian Yuridis Normatif dengan melihat, mempelajari dan memahami materi hukum terutama mengacu pada norma-norma yang mengatur tentang kelembagaan dan system pada perundang-undangan serta mekanisme menganalisis hokum. Sebagaimana dapat dilihat bahwa metode penelitian ini yang penulis lakukan adalah Library Researchatau dengan kata lain dengan cara metode kepustakaan. Hal ini diterapkan penulis dengan melakukan inventarisirkan data-data yang sudah ada, baik primer dan sekunder. Metode ini dapat juga digunakan untuk meneliti pada norma-norma yang berlaku dan terdapat dalam Perundang-undangan terhadap sistem upaya pemberantasan pengunaan Narkoba.

Sumber hukum yang digunakan dalam penelitian ini terdiri atas :

a. Bahan hukum primer, yaitu bahanbahan hukum yang mengikat seperti Kitab Undang-undang Hukum Pidana, Hak Asasi Manusia (HAM), dan Undang-undang Nomor 35 Tahun 2009 Tentang Narkotika.

b. Bahan hukum sekunder, yaitu bahanbahan yang erat kaitan hubungannya dengan penelitian ini, seperti : referensi buku dan makalah, karya ilmiah, jurnal,website (online).

Pengumpulan data dilakukan dengan cara melalui studi kepustakaan (Library Research), yakni melakukan penelitian dengan berbagai referensi bacaan, artikelartikel.

Analisis data dilakukan secara penelitian karena akan menjwab semua persoalan dan perkara yang timbul di kalangan masyarakat dan dari pokokpokok persoalan yang terjadi. Dan terdapat juga perundang-undangan di Indonesia yang berhubungan dengan permasalahan yang bersifat umum dijadikan sebagai pegangan untuk 
diterapkan kepada data yang diperoleh dari penelitian untuk memperoleh suatu kesimpulan. Analisis data juga dapat dilakukan setelah semua datanya terkumpul. Dalam penulisan ini, penulis menggunakan teknik deduktif dan induktif. Yaitu metode peraturan perundang-undangan yang sangat erat hubungannya dengan permasalah yang sifatnya umum.

\section{HASIL PENELITIAN DAN \\ PEMBAHASAN}

1. Penerapan Undang-Undang No. 35 Tahun 2009 Dalam Penegakan Hukum BagiPelaku Pengedar Narkotika

Penegakan hukumsebagai proses yang pada hakikatnya merupakan penerapan dikresi yang menyangkut membuat keputusan yang tidak secara ketat diatur oleh kaidah hukum, akan tetapi mempunyai unsur penilaian pribadi. Gangguan penegakan hukum mungkin terjadi, apabila ada ketidaksamaan "tritunggal" nilai, kaidah dan pola perilaku.

Narkotika adalah obat atau zat yang dapat menenangkan syaraf, mengakibatkan ketidaksadaran, atau pembiusan, menghilangkan rasa nyeri dan sakit, menimbulkanrasa mengantuk atau merangsang, dapat menimbulkan efek stupor,serta dapat menimbulkan adiksi atau kecanduan, dan yang ditetapkanoleh Menteri kesehatan sebagai Narkotika.

Penggolongan Narkotika di dalam Undang-Undang Nomor 35 Tahun2009, yaitu :

1. Narkotika golongan 1 adalah narkotika yang hanya dapat digunakan untuktujuan pengembangan ilmu pengetahuan dan tidak digunakan dalam terapiserta mempunyai potensi sangat tinggi, mengakibatkan ketergantungan

2. Narkotika golongan 2 adalah narkotika yang berkhasiat pengobatan, digunakan sebagai pilihan terakhir dan dapat digunakan dalam terapidan/atau untuk tujuan pengembangan ilmu pengetahuan serta mempunyaipotensi tinggi, mengakibatkan ketergantungan
3. Narkotika golongan 3 adalah narkotika yang berkhasiat pengobatan danbanyak digunakan dalam terapi dan/atau tujuan pengembangan ilmupengetahuan serta mempunyai potensi ringan, mengakibatkan ketergantungan.

Penghargaan diberikan kepada penegak hukum dan masyarakat yang telah berjasa dalam upaya pencegahan dan pemberantasan penyalahgunaan dan peredaran gelap Narkotika dan Prekursor Narkotika.

4. Hukuman yang dapat dijatuhkan kepada pengedar narkotika jenis sabu-sabu

Ketentuan pidana yang terdapat dalam UU No. 35 Tahun 2009 tentang Narkotika dirumuskan dalam Bab XV Ketentuan Pidana Pasal 111 sampai dengan Pasal 148. Undang-Undang No. 35 Tahun 2009 tentang Narkotika, terdapat empat kategorisasi tindakan melawan hukum yang dilarang oleh undang-undang dan dapat diancam dengan sanksi pidana, yakni:

a) Kategori pertama, yakni perbuatanperbuatan berupa memiliki, menyimpan, menguasai atau menyediakan narkotika dan prekurso narkotika;

b) Kategori kedua, yakni perbuatanperbuatan berupa memproduksi, mengimpor, mengekspor, atau menyalurkan narkotika dan prekursor narkotika;

c) Kategori ketiga, yakni perbuatanperbuatan berupa menawarkan untuk dijual, menjual, membeli, menerima, menjadi perantara dalam jual beli, menukar, atau menyerahkan narkotika dan prekursor narkotika;

d) Kategori keempat, yakni perbuatanperbuatan berupa membawa, mengirim, mengangkut atau mentransit narkotika dan prekursor narkotika;

Undang-Undang No. 35 Tahun 2009 tentang Narkotika telahmengatur jenisjenis sanksi yang diberikan pada tindak pidana narkotika antara lain: 
1. Tindak Pidana bagi penyalah guna atau sebagai korban penyalahgunaan narkotika, penyalah guna tersebut wajib menjalani rehabilitasi medis dan rehabilitasi sosial.

2. Tindak Pidana Orang Tua / Wali dari Pecandu Narkotika Narkotika yang Belum Cukup Umur (Pasal 128) dipidana dengan pidana kurungan paling lama 6 (enam) bulan atau pidana denda paling banyak $\mathrm{Rp}$ 1.000.000,00 (satu juta rupiah).

3. Tindak Pidana yang Dilakukan oleh Korporasi (Pasal 130) Dipidana dengan pidana penjara dan pidana denda dengan pemberatan 3 (tiga) kali.

4. Tindak pidana bagi Orang yang Tidak Melaporkan Adanya Tindak Pidana Narkotika (Pasal 131). Dipidana dengan pidana penjarapaling lama 1 (satu) tahun atau pidana denda paling banyak $\mathrm{Rp} 50.000 .000,00$ (lima puluh juta rupiah).

5. Tindak Pidana terhadap Percobaan dan Permufakatan Jahat Melakukan Tindak Pidana Narkotika dan Prekursor (Pasal 132) Ayat (1), dipidana dengan pidana pidana penjara yang sama sesuaidengan ketentuan sebagaimana dimaksud dalam Pasal-Pasaltersebut. Ayat (2), dipidana pidana penjara dan pidana dendamaksimumnya ditambah $1 / 3$ (sepertiga).

6. Tindak Pidana bagi Menyuruh, Memberi, Membujuk, Memaksa dengan Kekerasan, Tipu Muslihat, Membujuk Anak (Pasal 133) ayat(1), dipidana dengan pidana mati atau pidana penjara seumur hidup, atau pidana penjara 5 (lima) tahun paling singkat dan 20 (dua puluh) tahun palinglama dan pidana denda paling sedikit Rp 2.000.000.000,00 (dua miliar rupiah) dan paling banyak $\mathrm{Rp}$ 20.000.000.000,00 (dua puluh miliar rupiah). ayat (2), dipidanadengan pidana penjara paling singkat 5 (lima) tahun dan paling lama 15 (lima belas) tahun dan pidana denda paling sedikit Rp 1.000.000.000,00 (satu miliar rupiah) dan paling banyak Rp10.000.000.000,00 (sepuluh miliar rupiah).

7. Tindak Pidana bagi Pecandu Narkotika yang Tidak Melaporkan Diri (Pasal 134) ayat (1), dipidana dengan pidana kurungan paling lama6 (enam) bulan atau pidana denda paling banyak Rp 2.000.000,00 (dua juta rupiah). ayat (2), dipidana dengan pidana kurungan palinglama 3 (tiga) bulan atau pidana denda paling banyak Rp 1.000.000,00 (satu juta rupiah).

8. Tindak Pidana bagi Pengurus Industri Farmasi yang Tidak Melaksanakan Kewajiban (Pasal 135). Dipidana dengan pidanapenjara paling singkat 1 (satu) tahun dan paling lama 7 (tujuh) tahun dan pidana denda paling sedikit $\mathrm{Rp} 40.000 .000,00$ (empatpuluh juta rupiah) dan paling banyak Rp 400.000.000,00 (empat ratus juta rupiah).

9. Tindak Pidana terhadap Hasil-Hasil Tindak Pidana Narkotika dan/atau Prekursor Narkotika (Pasal 137) huruf (a), dipidana denganpidana penjara paling singkat 5 (lima) tahun dan paling lama 15(lima belas) tahun dan pidana denda paling sedikit Rp 1.000.000.000,00 (satu miliar rupiah) dan paling banyak Rp 10.000.000.000,00 (sepuluh miliar rupiah). Huruf (b), dipidana dengan pidana penjara paling singkat 3 (tiga) tahun dan palinglama 10 (sepuluh) tahun dan pidana denda paling sedikit $\mathrm{Rp}$ 500.000.000,00 (lima ratus juta rupiah) dan paling banyak Rp 5.000.000.000,00 (lima miliar rupiah).

10. Tindak Pidana terhadap Orang yang Menghalangi atau Mempersulit Penyidikan, Penuntutan dan Pemeriksaan Perkara (Pasal 138) Dipidana dengan pidana penjara paling lama 7 (tujuh) tahun danpidana denda paling banyak $\mathrm{Rp}$ $500.000 .000,00$ (lima ratus juta rupiah).

11. Tindak Pidana bagi Nahkoda atau Kapten Penerbang yang Tidak 
Melaksanakan Ketentuan Pasal 27 dan Pasal 28 (Pasal 139) dipidana dengan pidana penjara paling singkat 1 (satu) tahun dan palinglama 10 (sepuluh) tahun dan pidana denda paling sedikit $\mathrm{Rp} 100.000 .000,00$ (seratus juta rupiah) dan paling banyak Rp 1.000.000.000,00 (satu miliar rupiah).

12. Tindak Pidana bagi PPNS, Penyidik Polri, Penyidik BNN yang Tidak Melaksanakan Ketentuan tentang Barang Bukti (Pasal 140) dipidana dengan pidana penjara paling singkat 1 (satu) tahun danpaling lama 10 (sepuluh) tahun dan pidana denda paling sedikit $\mathrm{Rp} \mathrm{100.000.000,00}$ (seratus juta rupiah) dan paling banyak Rp 1.000.000.000,00 (satu miliar rupiah).

13. Tindak Pidana bagi Kepala Kejaksaan Negeri yang Tidak Melaksanakan Ketentuan Pasal 91 Ayat(1) (Pasal 141) dipidanadengan pidana penjara paling singkat 1 (satu) tahun dan palinglama 10 (sepuluh) tahun dan pidana denda paling sedikit $\mathrm{Rp}$ 100.000.000,00 (seratus juta rupiah) dan paling banyak $\mathrm{Rp}$ 1.000.000.000,00 (satu miliar rupiah).

14. Tindak Pidana bagi Petugas Laboratorium yang Memalsukan Hasil Pengujian (Pasal 142) dipidana dengan pidana penjara paling lama 7 (tujuh) tahun dan pidana denda paling banyak Rp 500.000.000,00 (lima ratus juta rupiah)

15. Tindak Pidana bagi Saksi yang Memberikan Keterangan Tidak Benar (Pasal 143) dipidana dengan pidana penjara paling singkat 1 (satu) tahun dan paling lama 10 (sepuluh) tahun dan pidana denda paling sedikit Rp 60.000.000,00 (enam puluh juta rupiah) dan paling banyak $\mathrm{Rp}$ $600.000 .000,00$ (enam ratus juta rupiah).

16. Tindak Pidana bagi Setiap Orang yang Melakukan Pengulangan Tindak Pidana (Pasal 144) dipidana dengan pidana maksimumnya ditambah dengan $1 / 3$ (sepertiga).
17. Tindak Pidana yang dilakukan Pimpinan Rumah Sakit, Pimpinan Lembaga Ilmu Pengetahuan, Pimpinan Industri Farmasi, dan Pimpinan Pedagang Farmasi (Pasal 147) dipidana dengan pidana penjara paling singkat 1 (satu) tahun dan paling lama 10 (sepuluh)tahun dan pidana denda paling sedikit Rp 100.000.000,00 (seratus juta rupiah) dan paling banyak Rp 1.000.000.000,00 (satu miliar rupiah).

5. Kebijakan Hakim Terhadap Tindak Pidana Sebagai Pengedar Narkotika Jenis Sabu-Sabu (Putusan Nomor 473/Pid.Sus/2015/Pt.Mdn)

Bermula pada hari Selasa tanggal 09 September 2014 sekira pukul 20.00 wib di simpang IV Tanjung Balai, terdakwa RAMLAN SIREGAR didatangi oleh temannya yang bernama HENDRA GUNAWAN (disidangkan dalam berkas perkara terpisah) dan saat itu Hendra Gunawan membeli narkotika jenis sabusabu kepada terdakwa sebanyak 1 (satu) gram seharga Rp. 500.000 (lima ratus ribu rupiah) dan selanjutnya pada hari Kamis tanggal 11 September 2014 sekira pukul 11.00 WIB, di Jl. Tritura Depan Swalayan Maju Bersama Kel Harjosari Kec Medan Amplas Kota Medan, Hendra Gunawan ditangkap oleh saksi KELLY WAHYUDI, saksi HERIYADI, saksi MUNIZAR, dan saksi SOZANOLO (masing-masing anggota sat narkoba Polresta Medan) dan menemukan barang bukti narkotika jenis sabu-sabu sebanyak 0,5 (nol koma lima) gram dari kantong belakang celana sebelah kirinya yang kemudian diakui oleh Hendra Gunawan bahwa narkotika jenis sabu-sabu yang ditemukan darinya tersebut dibelinya dari terdakwa Ramlan Siregar yang berada di Tanjung Balai Asahan, dan atas pengakuan dari Hendra Gunawan tersebut kemudian pada hari Jumat tanggal 12 September 2014 sekira pukul 04.30 wib, anggota polisi sat narkoba Polresta Medan tersebut melakukan penangkapan terhadap terdakwa di simpang kawat air batu Tanjung Balai Asahan dan saat 
diinterogasi terdakwa Ramlan Siregar mengakui bahwa mengenal Hendra Gunawan dan barang bukti narkotika jenis sabu-sabu yang ditemukan dari Hendra Gunawan tersebut yang dibeli oleh Hendra Gunawan dari terdakwa dan terdakwa mengakui bahwa pada hari Kamis tanggal 11 September 2014 sekira pukul 20.00 wib. Hingga diberikan upah oleh Amrih Prayoga, hingga pada hari Jumat tanggal 12 September 2014 sekira pukul 03.30 wib, terdakwa pergi ke Km 13 Tanjung Balai dan menunggu orang yang dimaksud oleh Amrih Prayoga dan tidak lama terdakwa berada ditempat tersebut, terdakwa didatangi oleh seorang laki-laki (belum tertangkap) suruhan Amrih Prayoga dan laki-laki tersebut menyerahkan 1 (satu) goni plastik berisikan 25 (dua puluh lima) bungkus plastik narkotika jenis sabu-sabu seberat 25 (dua puluh lima) Kg dan 6 (enam) bungkus plastik berisikan narkotika jenis pil ekstasy sebanyak 30.000 (tiga puluh ribu) butir seberat 10 (sepuluh) Kg dan setelah terdakwa menerima narkotika jenis sabu-sabu dan narkotika jenis pil ecstasy tersebut dari orang suruhan Amrih Prayoga lalu terdakwa pergi mengantarkan narkotika tersebut ke simpang kawat air batu dengan mengendarai 1 (satu) unit mobil Suzuki sidkick BK 1052 VN.

Dakwaan Jaksa Penuntut Umum terhadap pengedar narkotika jenis ganja yang dibacakan pada persidangan di Pengadilan Tinggi Medan yang pada pokoknya sebagai berikut :

Bahwa dia terdakwa RAMLAN SIREGAR bersama dengan RAHMAT SUWITO dan AMRIH PRAYOGA (masingmasing disidangkan dalam berkas perkara terpisah, pada hari Jumat tanggal 12 September 2014 sekira pukul 04.30 wib, atau setidak-tidaknya pada waktu lain masih dalam bulan September Tahun 2014 bertempat di simpang kawat air batu Tanjung Balai Asahan, yang karena saksi-saksi sebagian besar berkediaman di Medan dan sesuai pasal 84 ayat (2) KUHAP selanjutnya perkara ini dilimpahkan ke Pengadilan Negeri
Medan.Perbuatan mana dilakukan oleh terdakwa dengan cara sebagai berikut :

Bermula pada hari Selasa tanggal 09 September 2014 sekira pukul 20.00 wib di simpang IV Tanjung Balai, terdakwa RAMLAN SIREGAR didatangai oleh temannya yang bernama HENDRA GUNAWAN (disidangkan dalam berkas perkara terpisah) dan saat itu Hendra Gunawan membeli narkotika jenis sabu-sabu kepada terdakwa sebanyak 1 (satu) gram seharga Rp. 500.000 (lima ratus ribu rupiah).

Selanjutnya pada hari Kamis tanggal 11 September 2014 sekira pukul 11.00 WIB, di Jl. Tritura Depan Swalayan Maju Bersama Kel Harjosari Kec Medan Amplas Kota Medan, Hendra Gunawan ditangkap oleh saksi KELLY WAHYUDI, saksi HERIYADI, saksi MUNIZAR, dan saksi SOZANOLO (masing-masing anggota sat narkoba Polresta Medan) dan menemukan barang bukti narkotika jenis sabu-sabu sebanyak 0,5 (nol koma lima) gram dari kantong belakang celana sebelah kiri.

- Kemudian diakui oleh Hendra Gunawan bahwa narkotika jenis sabu-sabu yang ditemukan darinya tersebut dibelinya dari terdakwa Ramlan Siregar yang berada di Tanjung Balai Asahan, dan atas pengakuan dari Hendra Gunawan.

Setelahnya terdakwa didatangi oleh seorang laki-laki (belum tertangkap) suruhan Amrih Prayoga dan laki-laki tersebut menyerahkan 1 (satu) goni plastik berisikan 25 (dua puluh lima) bungkus plastik narkotika jenis sabusabu seberat 25 (dua puluh lima) $\mathrm{Kg}$ dan 6 (enam) bungkus plastik berisikan narkotika jenis pil ekstasy sebanyak 30.000 (tiga puluh ribu) butir seberat 10 (sepuluh) Kg dan setelah terdakwa menerima narkotika jenis sabu-sabu dan narkotika jenis pil ecstasy tersebut dari orang suruhan Amrih Prayoga lalu terdakwa pergi mengantarkan narkotika tersebut ke simpang kawat 
air batu dengan mengendarai 1 (satu) unit mobil Suzuki sidkick BK 1052 VN. - Bahwa terdakwa tidak mempunyai hak atau tidak memiliki izin untuk menjual, membeli, menerima, menjadi perantara dalam jual beli, menukar atau menyerahkan Narkotika.

Atas Perbuatan terdakwa sebagaimana diatur dan diancam pidana dalam Pasal 114 ayat (2) UU RI No 35 Tahun 2009 Tentang Narkotika jo Pasal 132 ayat (1) UU RI No 35 Tahun 2009 Tentang Narkotika.

Keterangan Saksi-saksi sebagai berikut :
a. Saksi 1 Rahmat Suwito dan Amrih Prayoga
b. Saksi 2 Hendra Gunawan
c. Keterangan terdakwa
d. Barang Bukti
e. Pertimbangan Hakim

\section{a) Analisis Penulis}

Berdasarkan hasil penelitian penulis, baik melalui membaca putusan hakim yang terkait dengan perkara dalam penulisan ini, maupun melalui studi kepustakaan dari dokumen terkait, maka penulis berkesimpulan bahwa sebelum menjatuhkan atau menetapkan putusan terhadap pelaku tindak pidana yang dilakukan, hakim terlebih dahulu mempertimbangkan banyak hal. Misalnya fakta-fakta pada persidangan, pertimbangan yuridis dan non-yuridis serta hal-hal lain yang terkait dalam tindak pidana yang dilakukan oleh terdakwa.

Sehingga, tidak membuat keliru dan menurut penulis bahwa Hakimpada tingkat pertama telah salah dan keliru dalam menerapkan hukum berkenaan dengan melakukan tindak pidan percobaan permufakatan jahat tanpa hak atau melawan hukum menjadi peranatar dalam jual-beli, menukar, menyerahkan atau menerima Narkotika Golongan I dalam bentuk bukan tanaman yang beratnya melebihi 5 gram sebagaimana diatur dalam pasal 114 ayat (2) Jo.pasal 132 ayat (1) Undang-Undang Nomor 35
Tahun 2009 tentang Narkotika (dakwaan pertama) diakitkan dengan fakta persidangan dalam perkara ini, karena berdasarkan fakta-fakta yang terungkap dimuka persidangan terdakwa RAMLAN SIREGAR tidak cukup bukti untuk dipersalahkan sebagaimana dakwaan dan tuntutan Jaksa Penuntut Umum dalam perkara ini.

Disini bisa kita lihat bahwa adanya kekeliruan pada penerapan hukum dari Hakim tersebut, sehingga seharusnya Hakim dapat memahami dan menguasi isi perkara agar dapat memutuskan putusannya yang lebih konkrit dan mutlak. Menurut saya, seharusnya juga Hakim dalam mejatuhkan pidana terhadap perkara ini harus mempertimbangkan keterangan terdakwa yang menyebutkan adanya transaksi jual beli dengan seseorang yang tidak dikenalnya. Dan didalam Pasal 114 ayat (1) Undang-Undang No. 35 tahun 2009 tentang Narkotika sebagaimana dalam dakwaan primair Jaksa Penuntut Umum tidak dituliskannya terkhusus pada narkotika golongan I bukan tanaman ataupun jenis tanaman.

Maka seharusnya Hakim menjatuhkan hukuman sesuai dengan tuntutan Jaksa Penuntut Umum dan memberikan sanksi yang setimpal terhadap pelaku tindak pidana tersebut sehingga supremasi hukum benar-benar ditegakkan dan tercipta ketertiban dalam masyarakat.

Jangan ada keraguan dalam menjatuhkan hukuman sebagaimana juga suatu tindak pidana harus mendapat imbalan atau hukuman yang sepantasnya, karena hukuman selain dijadikan suatu balasan atas tindak pidana dapat juga sebagai perbaikan dan pencegahan akan semakin maraknya tindak pidana.

Berhasilnya suatu proses penegakkan hukum sangat bergantung pada penerapan hukum pidana, diana peranan penegak hukum salah satunya adalah bagaimana engaktualisasikan dengan baik didunia nyata.

Surat dakwaan adalah dasar atau landasan pemeriksaan perkara didalam 
sidang pengadilan sedangkan surat tuntutan adalah surat yang berisi tuntutan penuntut umum terhadap suatu tindak pidana. Pada hakikatnya seorang Jaksa Penuntut Umum harus membuat surat dakwaan dan surat tuntutan yang membuat pelaku/terdakwa suatu tindak pidana tidak dapat lolos dari jeratan hukum.

Hakim dalam memeriksa suatu perkara tidak boleh menyimmpang dari apa yang dirumuskan didalam surat dakwaan. Seorang terdakwa hanya dapat dijatuhi hukuman karena telah dibuktikan dalam persidangan bahwa ia telah melakukan tindak pidana seperti apa yang disebutkan atau dinyatakan jaksa dalam surat dakwaan.

Surat Dakwaan Jaksa Penuntut Umum dalam perkara ini secara teknis telah memenuhi syarat formal dan materil surat dakwaan sebagaimana dimaksud Pasal 143 KUHAP, yaitu harus memuat tanggal dan ditandatangani oleh penuntut umum serta identitas lengkap terdakwa, selain itu juga harus memuat uraian secara cermat,jenis dan lengkap mengenai tindak pidana didakwakan dengan menyebutkan waktu dan tempat tindak pidana dilakukan.

Akan tetapi penulis melihat berdasarkan keterangan saksi-saksi dan keterangan terdakwa, terungkap bahwa terdakwa mengakui secara tanpa hak atau melawan hukum menjual atau menjadi perantaradalam transaksi jual beli dan turut bersama-sama melakukan tindak pidana tersebut dengan seseorang yang bernama Hendra Gunawan dan seorang laki-laki suruhan Amrih Prayoga yang belum tertangkap, hal ini juga diakui oleh saksi-saksi yang merupakan anggota dari Polisi Sat Narkoba Polresta Medan.

\section{KESIMPULAN}

Dari rumusan masalah, berdasarkan hasil penelitian dan pembahasan yang telah diuraikan diatas, maka penulis dapat menarik kesimpulan sebagai berikut : b. Penegak hukum dalam melakukan penangkalan dan penanggulangan terhadap suatu tindak pidana sangat diharapkan masyarakan agar lebih ditingkatkan. Mengapa? Agar tidak terjadinya kesimpang-siuran antara sesama penegak hukum berupa penegakan hokum yang dilakukan oleh profesionalisme yang benar-benar ahli di bidangnya serta memiliki pengalaman kasus berkaitan dengan bidang yang sudah ditanganinya. Dan sangat pengaruh besar-kecilnya dari dukungan pemerintahan yang bersih dalam membangun penegakan hukum yang akuntabel harus total, karena penegakan hukum adalah bagian dari sistem hukum pemerintahan.

c. Upaya Hukum di Indonesia sebaiknya memperkuatkan system proses penghukumannya, seperti dilakukannya penegakan aparatur Negara dalam melindungi masyarakat agar terhindar dari penyalahgunaan narkotika, dan upaya hukum ini juga dapat menstabilkan diantara kesimpangsiuran hukuman yang di Indonesia.

d. Penerapan ketentuan hukum pidana materil terhadap perkara putusan

Nomor :473/PID.SUS/2015/PT. MDNmenurut penulis mestinya sesuai dengan tuntutan dari Jaksa Penuntut Umum. Karena dalam keterangan terdakwa yang dikemukakan dalam persidangan mengatakan adanya transaksi jual beli yang dilakukan oleh terdakwa dengan seseorang yang tidak dikenalnya karena suruhan orang AMRIH PRAYOGA. 
e. Pertimbangan Hukum Hakim dalam menjatuhkan sanksi pidana perkara putusan Nomor : 473/PID.SUS/2015/PT.MDN berdasarkan pertimbangan Penuntut Umum dan Hakim maka sanksi yang dijatuhkan mestinya tidak hanya membebaskan Terdakwa RAMLAN SIREGAR dari dakwaan KEDUA melanggar Pasal 112 ayat (2) jo Pasal 132 ayat (1) UU RI No. 35 Tahun 2009 tentang Narkotika tersebut.

\section{DAFTAR PUSTAKA}

\section{A. Buku}

Adami, Chazawi. 2002. Pelajaran Hukum Pidana, Bagian 2; Penafsiran Hukum Pidana, Dasar Peniadaan, Pemberatan \& Peringanan, Kejahatan Aduan, Perbarengan \& Ajaran Kausalitas.

Anonim, Penyalahgunaan Narkotika dan Obat-obatan Terlarang Di Kalangan Remaja serta Akibat dan Antisipasinya.DPC Granat.Surakarta

Amir, Ilyas. 2013. Asas-Asas Hukum Pidana 2. Jakarta: Rangkang.

Dikdik, M.Arief Mansur dan Elisatris, Gultom. 2007. Urgensi Perlindungan Korban Kejahatan, PT. Raja Grafindo Persada, Jakarta.

H.Dadang, Hawari. 2003. Penyalahgunaan dan ketergantungan NAPZA,FK-UI Jakarta.

I Made Widnyana. 2010. Asas-Asas Hukum Pidana, Cetakan Pertama. Jakarta: PT. Fikahati Aneska.

Korp Reserce Polri Direktorat Reserce Narkoba. 2000. Peranan Generasi Muda dalam Pemberantasan narkoba. Jakarta.
Mardani. H. 2008.Penyalahgunaan Narkoba Dalam Perspektif HukumIslam Dan Hukum Pidana Nasional. Jakarta: PT. Raja GrafindoPersada.

Marpaung, Leden. 2005. Asas-TeoriPraktik Hukum Pidana, Jakarta: Sinar Gratifika.

Menguak Teori Hukum Legal (Legal Theory) dan Teori Peradilan (Judicialprudence).Jakarta : Kencana Prenada Media Grup.

Moh. Taufik Makarao,Suhasril, dan Moh.Zakky A.S. 2005. Tindak Pidana Narkotika. Jakarta: Ghalia Indonesia.

Pemberantasan Korupsi Melalui Hukum Pidana Nasional dan Internasional. 2007. Jakarta : Rajawali Press.

Tolib, Setiady. 2010. Pokok-Pokok Hukum Penitensier Indonesia. Bandung: Alfabeta.

P.A.F, Lamintang. 1990. Dasar-dasar Hukum Pidana Indonesia. Bandung: Sinar Baru.

Prof. Dr. Soerjono Soekanto. 2013. Faktor-faktor yang mempengaruhi penegakan hukum. Jakarta: Rajawali pers.

Roeslan, Saleh. 1983. Perbuatan Pidana dan Pertanggungjawaban Pidana. Jakarta: PT Aksara Baru

Soedjono. 1997. Patologi Sosial, Bandung: Alumni Bandung.

Wirjono, Prodjodikoro. 2003. Asas-asas Hukum Pidana Di Indonesia. Bandung: Repika Aditama.

Muladi dan Barda Nawawi Arief. 1998. Teori-teori dan Kebijakan Pidana. Bandung: Alumni Bandung.

\section{B. Peraturan Perundang-Undangan}

Kitab Undang-Undang Hukum Pidana (KUHP) Serta KementarKomentarnya Lengkap Pasal Demi Pasal.Bogor : Politea. 
KUHP dan KUHAP Dilengkapi Yurisprudensi Mahkama Agung dan Hoge Raad, Jakarta : Rajawali Press.

Undang-Undang Nomor 35 Tahun 2009 Tentang Narkotika.

\section{Internet :}

http://www.hmihukumugm.org/2015/04/ penegakan-hukum-dalampemberantasan.html.

http://repository.unhas.ac.id/bitstream/ha ndle/123456789/16279/JURNA

L\%20LENGKAP-PIDANAMUHAMMAD\%20IRFAN\%20 UMAR.

http://www.negarahukum.com/hukum/pe ngertian-narkotika.html.

http://repository.unhas.ac.id/bitstream/ha ndle/123456789/9158/JURNAL $\% 20$ LENGKAP-PIDANAARYA\%20FITRI.

Agusy. 2012. Pemidanaan Terhadap Pengedar Narkoba. http://pnkepanjen.go.id.

http://hukumpidana1.blogspot.com/2012/ 03/macam-macam-hukumanatau-pidana.html

http://www.ikonbali.org/09/03/2010/dok umentasi/sema-dan-legitimasidekriminalisasi-pecandu.html. diakses pada tanggal 31 Januari 2019, jam 15.30

http://jurnal.umrah.ac.id/wpcontent/uplo ads/gravity_forms/1ec61c9cb232a03a96d0947c647 $8 \mathrm{e} 525 \mathrm{e} / 20 \quad 15 / 09 /$ E-jurnaljimmy.pdf 